\title{
Risk Management For Unexploded Ordinance (UXO) In The Marine Environment
}

\begin{abstract}
After World Wars I and II large amounts of explosive ordnance remained undetonated. Already deployed ordnance was left uncollected and excess supplies were disposed of, sometimes recklessly. The result is that much of this unexploded ordnance (UXO) still exists in the environment, much of it throughout the world's oceans, where it continuously presents a risk of serious harm to people and the environment. The purpose of this paper is to present a marine UXO risk assessment that could aid managers working in marine industries in mitigating the risks presented by marine UXOs. Using existing marine UXO literature, a list of 21 plausible UXO risk events was generated and then categorized into risk levels of low, medium, high, and very high using a novel risk matrix approach. The common pathways that determine interactions between people and marine UXOs were identified and the efficacy of a series of risk mitigation strategies were examined within the context of the identified risks.
\end{abstract}

\begin{abstract}
About the Authors: Jana Aker is a graduate student in the Marine Affairs Program at Dalhousie University. She is originally from Sydney, Nova Scotia, and obtained her undergraduate degree in biology from Cape Breton University in 2010. Her interests include marine protected areas, conservation and shipping impacts and regulations. In summer 2012 she will be involved with the establishment of the St. Ann's Bank marine protected area off of the east coast of Cape Breton Island. Jana can be reached at jana.aker@dal.ca.
\end{abstract}

Brett Howard is a Master of Marine Management Candidate at the Dalhousie University Faculty of Management. She has a background in marine ecology and conservation and is interested in the interface between marine science and international law and policy. Her career aspirations are to help develop marine management strategies that encourage sustainable and safe marine resource extraction. Brett can be reached at brett.howard@dal.ca.

Mike Reid is a Candidate in the Masters of Marine Management program at Dalhousie University. His research interests include maritime history, wetland management practices and the politics of commercial activity on and under the high seas. He is currently preparing to undertake a project that will attempt to establish historical baselines for wetland coverage within the province of Nova Scotia. Mike can be reached at pmreid@dal.ca. 


\section{Introduction}

World Wars I and II resulted in the production of large quantities of ordnances (munitions). Unfortunately, many of these legacy ordnances persist in an unexploded state; both on land and in the world's oceans, presenting the risk of serious harm to people and the environment. Unexploded ordnances (UXOs) are explosive chemical or conventional munitions that, at the time of deployment or discard, were prepared for use but not detonated either deliberately or through malfunction (Alpha Associates, 2011a). UXOs are a concern for individuals currently working in marine industries, including but not limited to, fishing, oil and gas exploration, and telecommunications. These individuals are at risk of unexpectedly encountering unexploded ordnances in their daily work, the results of which could be devastating. The purpose of this paper is to review the risks presented by UXOs in the marine environment and develop a set of risk assessment tools that can be used by managers working in marine industries to prioritize their UXO risk management strategies. These tools include a risk assessment matrix, a characterization of the typical interaction pathways between people and UXOs, and a review of available mitigation options based on the results of the assessment.

In the marine environment, UXOs typically include sea mines, torpedoes, depth charges, mustard gas and other chemical weapons, munitions dumps, and wrecks of munitions-laden ships. It is estimated that during World War II, 10 percent of the military ordnances that were deployed in the marine environment surrounding the United Kingdom (UK) failed to detonate (Alpha Associates, 2011a).

Chemical ordnances are munitions and devices specifically designed to cause death or harm through toxic chemicals, which release upon deployment (Organization for the Prohibition of Chemical Weapons, 1993). Some chemical weapons reportedly dumped by the United States Army contain sulfur, mustard, and nerve agents (Bearden, 2007). During World War II, Canada was one of the largest producers of such chemical and biological weapons. Following the war, it was standard procedure to bury these ordnances on land or dump them in the ocean (Department of National Defense, 2003). It is reported that in 1946, the Canadian Navy dumped approximately 11,000 170-litre drums of mustard gas in Canadian waters, sometimes sinking entire ships with the drums still onboard (Kehoe, 2002). Following World War II, approximately 40,000 tons of chemical weapons containing 13,000 tons of chemical warfare agents, including mustard gas, chloroacetophenone, and adamsite, were dumped in the Baltic Sea by the former Soviet Union (HELCOM, 1994).

Chemical weapons pose an unknown risk to the marine environment and serious risk to those who discover them, particularly fishermen (Department of National Defense, 2003). The environmental impact of chemical munitions is, for the most part, assumed to be negligible because of the vastness of the ocean and the belief that toxic concentrations cannot reach levels high enough to be dangerous to the environment. The exception to this is mustard gas, 
which has known toxicological effects and takes a very long time to decompose in water, plasticizing into thick ooze. Dangerous concentrations of mustard gas have been found in the sediments surrounding underwater dumpsites (HELCOM, 1994). Incidences of fishing boats hauling up chemical weapons containing mustard gas have been reported. In 2010, the crew of a fishing boat in Massachusetts accidentally hauled up two military shells containing mustard gas and suffered painful blisters over large portions of their bodies from exposure to the polymerized mustard (Lindsay, 2010).

The biggest risk posed by conventional marine UXOs is accidental detonation under uncontrolled conditions resulting in loss of life, injury, or property damage. Conventional ordnances tend to contain explosive substances, such as trinitrotoluene (TNT), primarily used to damage ships and infrastructure (Beddington and Kinloch, 2005). Sea mines, large floating bombs containing hundreds of pounds of explosives (Slate, 2000), were moored beneath the surface of the water where they were meant to explode upon contact with a ship. During World War I, over 128,000 sea mines were deployed in the marine environment around the UK, and approximately 100,000 were deployed in the North Sea and the Thames Estuary during World War II. There is no record of minesweeping after WWI and there was only a 15 to 30 percent recovery rate of sea mines after WWII, which suggests that there could be up to 190,000 undetonated sea mines still surrounding the UK (Alpha Associates, 2011a). Worldwide, it is estimated that over 550,000 sea mines were deployed during WWII, and since there is no record of how many of these mines were either detonated during the war or recovered afterward, it is unknown how many remain (Slate, 2000).

Torpedoes were launched into the water where their explosive warheads ideally detonated on contact with ships and submarines (Department of National Defense, 2010a). German-made warheads in World War II were known to be unreliable and many exploded before making contact with a target, while others failed to detonate. Torpedoes that failed to detonate settled to the sea floor with the warhead still attached (Alpha Associates, 2011a). Depth charges are essentially drums of explosives that are designed to detonate underwater (Mckee, 1993). Although deployment of depth charges in WWII was less frequent than other ordnance types, it is unknown how many failed to detonate (Alpha Associates, 2011a).

Shipwrecks, especially those that occurred during the world wars, are another source of UXOs in the marine environment. For example, when the H.M.S Royal Oak was sunk in Scapa Bay, Scotland by a German U-boat it took all of its ordnances with it, where they remain today (Westman, 2006). Shipwrecks have been largely well-recorded in nautical charts, providing a valuable reference for locating UXO-laden wrecks. Wrecks that contain ordnances are considered to be extremely dangerous and when one is found, it is usually left undisturbed (Alpha Associates, 2011). It is estimated that during World War II, approximately 3,800 warships were sunk in the East Asian Pacific Ocean alone, many of which would have had ordnances onboard (Monfils, Gilbert \& Nawadra, 2006). 
Following the World Wars, surplus conventional and chemical ordnances were routinely disposed of by dumping them into the ocean. This practice has been used throughout the world's oceans. It is estimated that the UK alone disposed of over 1.1 million tons of chemical and conventional munitions into the marine environment (Alpha Associates, 2011a). This method is one of the more dangerous strategies for munitions disposal, compared to burning or open detonation, because the number of explosives and location of the dumpsites are not always recorded (Kmec et al., 2010).

Since the World Wars, marine industries such as tourism, fishing, energy exploration, and telecommunications have grown. Because marine UXOs have the potential to detonate if disturbed, and their locations are often unknown, there is an increasing risk of an accidental encounter between the public and a marine UXO (Department of National Defense, 2010b). The Canadian Government, through its UXO Legacy Program, is researching and mapping locations of UXOs in Canadian waters, and where possible, removing or detonating them (Department of National Defense, 2010b). There are also private companies that specialize in the detection and removal of UXOs. These companies are usually contracted by oil exploration, dredging operations, underwater pipeline, and mining companies before they begin exploration or construction (Alpha Associates, 2011b). While there are professional and government officials working to find and decommission underwater UXOs, there are still incidents of UXOs being unintentionally found and accidentally detonated. There are many reports of fishermen bringing unexploded ordnances up in their trawling nets but in most cases, the ordnance is simply returned to the marine environment (Beddington and Kinloch, 2005). Given the variety of possible interactions between marine UXOs, the marine environment, and people, there is a need to determine the level of risk each of these interactions poses.

\section{Analysis of the Risks of Marine UXOs}

\section{Risk Matrix}

An independent risk assessment of the risks posed by marine UXOs is confounded by two factors. The first is that data collected on UXO location, discovery, and consequences is not consolidated in any one publicly accessible, comprehensive database. The second factor is that much of the known information about marine UXOs is of a proprietary nature and belongs to private UXO detection and disposal companies. Therefore, in order to generate an appropriate risk matrix for marine UXOs, a number of assumptions have to be made based on the available primary and secondary literature.

The first assumption is that an interaction with a UXO in the marine environment can result in multiple consequences that are not mutually exclusive. For example, a UXO accidentally brought up in a fishing trawl may explode, causing damage to the boat or even injury or death 
to its crewmembers. To generate the most comprehensive assessment of the severity of consequences of a UXO risk event, risk was calculated using the "worst case scenario", assuming that all possible negative consequences occurred in the event. Since the possible consequences of a marine UXO are broad in scope and often speculative, four major categories of consequence types were determined, based on existing literature: property damage, environmental damage, location unknown, and personal injury/exposure/death; all of the consequences of UXOs discovered in the literature fit into one of these four categories. The second assumption was made in regards to the assignment of relative levels of damage severity (Table 1). For example, property damage was assumed to be a less severe consequence than environmental damage, personal injury or death. Consequently, a UXO event could have a severity rating of between 0 (if none of the consequence categories applied) and 10 (if all four categories applied) (Box 1).

Table 1: The four categories of consequences that occur when UXOs are encountered by people or exposed to the marine environment, the relative severity of each category and the justification for the ranking.

\begin{tabular}{|l|l|l|}
\hline $\begin{array}{l}\text { Possible } \\
\text { Consequence }\end{array}$ & $\begin{array}{l}\text { Relative } \\
\text { Severity }\end{array}$ & Justification \\
\hline $\begin{array}{l}\text { Property } \\
\text { damage }\end{array}$ & 1 & $\begin{array}{l}\text { Includes primarily damage to vessels but also fishing, dredging or } \\
\text { mining equipment, and private and public buildings. It was given } \\
\text { the lowest relative severity rating because property damage is } \\
\text { almost always a recoverable loss, through repair and/or insurance. }\end{array}$ \\
\hline $\begin{array}{l}\text { Environmental } \\
\text { damage }\end{array}$ & 2 & $\begin{array}{l}\text { Includes, but is not limited to, direct toxic effects to marine } \\
\text { organisms, bioaccumulation in the food web, and the effects of } \\
\text { pressure changes on marine mammals and fish caused by } \\
\text { underwater explosions. These consequences are difficult to } \\
\text { measure and generally considered to be negligible. }\end{array}$ \\
\hline $\begin{array}{l}\text { Location } \\
\text { unknown }\end{array}$ & 3 & $\begin{array}{l}\text { Includes a UXO that remains undiscovered, unreported, or was } \\
\text { sold or relocated illegally. These UXOs must be assumed to still be } \\
\text { a threat to property, the environment and people. }\end{array}$ \\
\hline $\begin{array}{l}\text { Injuries, } \\
\text { exposure, or } \\
\text { death }\end{array}$ & 4 & $\begin{array}{l}\text { Includes the risk that UXO disposal experts and bystanders are } \\
\text { harmed in the detection and disposal process. Ranked the highest } \\
\text { due to the long-lasting and often unrecoverable damage that can } \\
\text { be done when people interact with UXOs. }\end{array}$ \\
\hline
\end{tabular}




\section{Box 1: An example of how consequence severity was calculated.}

A UXO that is accidently surfaced in fishing gear and is reported to authorities could result in:

..property damage?

...damage to the environment?

..its location being unknown?

...injuries, exposure or death?
$+1$

$\mathrm{X}$

$\mathrm{X}$

$+0$

$+4$

Total value of consequence severity $=$

$$
5
$$

Using marine UXO review papers, which are typically government and non-governmental organization publications, a list of 21 plausible UXO risk events in the marine environment was generated (Table 2). The parameters for inclusion were that risk events occurred in the marine environment and involved risk to people and/or the environment. For completeness, interactions that were hypothesized to be possible, either in the literature or by the authors, but were undetectable or unrecorded, were also included in the list.

Table 2: UXO risk events were determined through a literature review. Some risk events were known to occur and had associated data on frequency of occurrence. Some were assumed to occur but did not have associated data on frequency, as events go undetected or unreported $\left({ }^{*}\right)$. Events the authors of this paper considered plausible based on the literature review were also included $\left({ }^{* *}\right)$.

\begin{tabular}{|l|l|l|}
\hline \multicolumn{1}{|c|}{ UXO Risk Event } & \multicolumn{1}{|c|}{$\begin{array}{c}\text { Examples of Known } \\
\text { Frequency of Occurrence }\end{array}$} & \multicolumn{1}{c|}{ Literature Sources } \\
\hline $\begin{array}{l}\text { Accidentally detonated by diver } \\
\text { or similar recreational activity ** }\end{array}$ & N/A & N/A \\
\hline $\begin{array}{l}\text { Accidentally detonated due to } \\
\text { boat collision ** }\end{array}$ & N/A & N/A \\
\hline $\begin{array}{l}\text { Caught in fishing net but not } \\
\text { surfaced, redistributed in the } \\
\text { marine environment* }\end{array}$ & N/A & $\begin{array}{l}\text { Beddington \& Kinloch, } \\
2005\end{array}$ \\
\hline $\begin{array}{l}\text { Chemical agent: insoluble, able } \\
\text { to bioaccumulate in marine } \\
\text { organisms }\end{array}$ & N/A & $\begin{array}{l}\text { Beddington \& Kinloch, } \\
2005 ; \text { En et al., 2005; } \\
\text { Glasby, 1997 }\end{array}$ \\
\hline $\begin{array}{l}\text { Chemical agent: polymerizes } \\
\text { over time/exposure and surfaced } \\
\text { in fishing gear }\end{array}$ & $\begin{array}{l}\text { Denmark, most of the injuries } \\
\text { that occur from chemical } \\
\text { munitions dumped in the } \\
\text { marine environment are to } \\
\text { fishermen surfacing } \\
\text { plasticized mustard. }\end{array}$ & $\begin{array}{l}\text { Beddington \& Kinloch, } \\
\text { 2005; Glasby, 1997; } \\
\text { OSPAR, 2010 }\end{array}$ \\
\hline
\end{tabular}




\begin{tabular}{|c|c|c|}
\hline Chemical agent: soluble in water & $\mathrm{N} / \mathrm{A}$ & $\begin{array}{l}\text { Beddington \& Kinloch, } \\
\text { 2005; HELCOM } 1994\end{array}$ \\
\hline $\begin{array}{l}\text { Chemical agent: insoluble, } \\
\text { remains toxic }\end{array}$ & $\mathrm{N} / \mathrm{A}$ & $\begin{array}{l}\text { Green et al., 1999; } \\
\text { Lotufo et al., 2001; } \\
\text { Nipper et al., } 2001\end{array}$ \\
\hline $\begin{array}{l}\text { Detonation results in } \\
\text { oceanographic/seismic activity ** }\end{array}$ & $\mathrm{N} / \mathrm{A}$ & $\mathrm{N} / \mathrm{A}$ \\
\hline $\begin{array}{l}\text { Discovered accidentally but left } \\
\text { undisturbed or returned to the } \\
\text { marine environment }\end{array}$ & $\begin{array}{l}\text { Most literature supports a } \\
\text { policy of leaving known UXO } \\
\text { sites undisturbed. In one year, } \\
11 \text { percent of reported UXOs } \\
\text { were returned to the ocean. }\end{array}$ & $\begin{array}{l}\text { Beddington \& Kinloch, } \\
\text { 2005; OSPAR, } 2010\end{array}$ \\
\hline $\begin{array}{l}\text { Discovered accidentally by diver: } \\
\text { reported * }\end{array}$ & $\mathrm{N} / \mathrm{A}$ & $\begin{array}{l}\text { Monfils, Gilbert, \& } \\
\text { Nawadra, } 2006\end{array}$ \\
\hline $\begin{array}{l}\text { Intentionally detonated or } \\
\text { neutralized in situ }\end{array}$ & $\begin{array}{l}\text { In one year, } 76 \text { percent of } \\
\text { discovered UXOs were } \\
\text { removed from the ocean or } \\
\text { neutralized. }\end{array}$ & $\begin{array}{l}\text { Cullison \& Turlington, } \\
\text { 2004; Halpin \& } \\
\text { Morrison, 2009; } \\
\text { Kockinski \& Kock, 2009; } \\
\text { OSPAR, } 2010\end{array}$ \\
\hline $\begin{array}{l}\text { Intentionally removed for } \\
\text { detonation }\end{array}$ & $\mathrm{N} / \mathrm{A}$ & OSPAR, 2010 \\
\hline $\begin{array}{l}\text { Recovered intact and sold or } \\
\text { redeployed illicitly * }\end{array}$ & $\mathrm{N} / \mathrm{A}$ & Slade, 2000 \\
\hline $\begin{array}{l}\text { Redistributed in the marine } \\
\text { environment by dredging or } \\
\text { mining operations * }\end{array}$ & $\mathrm{N} / \mathrm{A}$ & $\begin{array}{l}\text { Beddington \& Kinloch, } \\
\text { 2005; OSPAR, } 2010\end{array}$ \\
\hline $\begin{array}{l}\text { Spontaneous detonation } \\
\text { underwater * }\end{array}$ & $\begin{array}{l}\text { 36 times a year in the Irish } \\
\text { Sea, assumed. }\end{array}$ & $\begin{array}{l}\text { Beddington \& Kinloch, } \\
\text { 2005, Davies, 1996; } \\
\text { Kirby, } 2004\end{array}$ \\
\hline $\begin{array}{l}\text { Surfaced by dredging or mining } \\
\text { operations * }\end{array}$ & $\mathrm{N} / \mathrm{A}$ & $\begin{array}{l}\text { OSPAR, 2010; ACOPS, } \\
\text { 2003; Crown, } 2010\end{array}$ \\
\hline $\begin{array}{l}\text { Surfaced due to its own } \\
\text { buoyancy * }\end{array}$ & $\mathrm{N} / \mathrm{A}$ & $\begin{array}{l}\text { Beddington \& Kinloch, } \\
\text { 2005; OSPAR } 2010\end{array}$ \\
\hline Surfaced due to weather events & $\begin{array}{l}\text { In one year, } 29 \text { percent of } \\
\text { discovered UXOs were found } \\
\text { on the shore; weather is } \\
\text { assumed to be a major cause } \\
\text { of this (although dredging and } \\
\text { mining operations may also be } \\
\text { a cause). }\end{array}$ & $\begin{array}{l}\text { Beddington \& Kinloch, } \\
\text { 2005; HELCOM, 1996; } \\
\text { OSPAR, } 2010\end{array}$ \\
\hline
\end{tabular}




\begin{tabular}{|l|l|l|}
\hline $\begin{array}{l}\text { Surfaced in fishing nets: landed } \\
\text { in port }\end{array}$ & $\begin{array}{l}52 \text { known incidents in one } \\
\text { year in the UK. }\end{array}$ & ACOPS, 2003 \\
\hline $\begin{array}{l}\text { Surfaced in fishing nets: not } \\
\text { reported }\end{array}$ & N/A & ACOPS, 2003 \\
\hline $\begin{array}{l}\text { Surfaced in fishing nets: } \\
\text { reported }\end{array}$ & $\begin{array}{l}\text { Hundreds of reports in the UK, } \\
\begin{array}{l}58 \text { percent of reported } \\
\text { munitions per year are } \\
\text { encountered by fishermen. }\end{array}\end{array}$ & $\begin{array}{l}\text { ACOPS, 2003; OSPAR, } \\
2010\end{array}$ \\
\hline
\end{tabular}

The worldwide frequency of these identified UXO risk events was gathered from the literature, where possible (Table 2). It must be noted that much of the quantitative information was restricted to European studies, and even then, the frequency of most risk events was unknown or assumed. Therefore, frequency was inferred from the literature based on an estimate of how common the event was; this became the measure of likelihood of occurrence on a scale of uncommon to very common (Table 3). When the likelihood was unknown (assumed), it was given a higher relative value than a known likelihood. This was done to incorporate the additional risk of uncertainty, given the assumption that an unknown risk is more dangerous than a known one.

Table 3: The likelihood that a UXO risk event will occur, the relative value of each likelihood and the number of risk events that were classified into each category $(n=21)$. When likelihood of occurrence was assumed, it was given a higher relative value, to incorporate the risk of uncertainty.

\begin{tabular}{|c|c|c|c|}
\hline $\begin{array}{l}\text { Likelihood of } \\
\text { Occurrence }\end{array}$ & Criteria & $\begin{array}{l}\text { Relativ } \\
\text { e Value }\end{array}$ & $\begin{array}{c}\text { Number of Risk } \\
\text { Events with this } \\
\text { Likelihood }\end{array}$ \\
\hline Uncommon & \multirow{2}{*}{$\begin{array}{l}\text { Known to occur but } \\
\text { exceptionally rare; very few if } \\
\text { any documented cases. More } \\
\text { research is needed. }\end{array}$} & 1 & 3 \\
\hline Assumed uncommon & & 2 & 8 \\
\hline Slightly common & \multirow{2}{*}{$\begin{array}{l}\text { Where occurrence has been } \\
\text { quantified there are typically } \\
<50 \text { occurrences per year per } \\
\text { country. }\end{array}$} & 3 & 2 \\
\hline $\begin{array}{l}\text { Assumed slightly } \\
\text { common }\end{array}$ & & 4 & 2 \\
\hline Common & \multirow{2}{*}{$\begin{array}{l}\text { Where occurrence has been } \\
\text { quantified there are between } \\
50-100 \text { occurrences per year } \\
\text { per country, but many are } \\
\text { anecdotal. }\end{array}$} & 5 & 0 \\
\hline Assumed common & & 6 & 1 \\
\hline
\end{tabular}




\begin{tabular}{|l|c|c|c|}
\hline Very common & Occurrences are frequent and & 7 & 5 \\
\cline { 1 - 1 } $\begin{array}{l}\text { Assumed very } \\
\text { common }\end{array}$ & $\begin{array}{c}\text { unmonly known; many are } \\
\text { Estimated at over 100 per year } \\
\text { per country. }\end{array}$ & 8 & 0 \\
\hline & \multicolumn{2}{|r|}{ Total number of risks identified $=21$} \\
\hline
\end{tabular}

The consequence severity calculation (Box 1) was applied to the 21 UXO risk events (Table 2), and the likelihood of occurrence for each was determined or approximated (Table 3). These two scales were used to generate a risk matrix for UXO risks in the marine environment (Table 4). The matrix estimates risk based on the consequence severity and likelihood of the event occurring, which allows a risk priority to be set for each event, ranging from low (yellow) to very high (red). The determined risk priority for all 21 risk events, including their consequence severity and likelihood of occurrence, is summarized in Table 5. 
Table 4: A risk priority matrix for marine UXO risks, based on consequence severity and likelihood of the event occurring. The priority ranges from low (yellow, top left corner) to very high (red, bottom right corner). The black cells could be treated as extreme priority; however none of the 21 risk events identified in this paper fell into that category. White cells indicate there is no risk because the consequence value is zero.

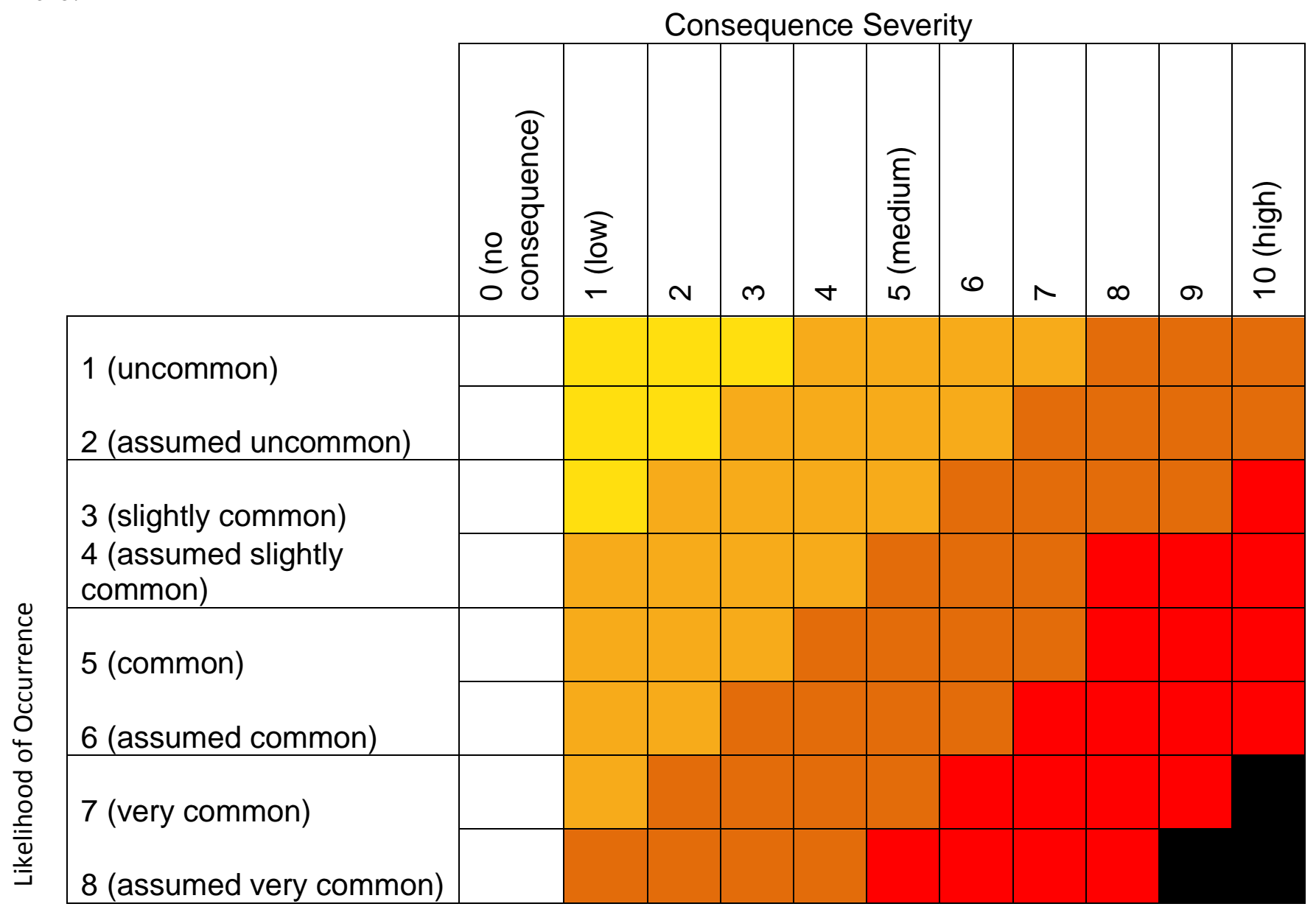


Table 5: The risk priorities for 21 marine UXO risk events were determined by combining the consequences of the risk (Table 1) and the likelihood of the risk event occurring (Table 3 ) in the risk matrix (Table 4). Risk priority is ranked from low to very high.

\begin{tabular}{|l|c|c|c|}
\hline \multicolumn{1}{|c|}{ Risk Event } & $\begin{array}{c}\text { Severity of } \\
\text { Consequenc } \\
\text { es }\end{array}$ & $\begin{array}{c}\text { Likelihood } \\
\text { of } \\
\text { Occurrenc }\end{array}$ & Priority \\
\hline Chemical agent: soluble in water & 0 & 1 & none \\
\hline Chemical agent: insoluble, able to & 2 & 1 & low \\
\hline Chemical agent: insoluble, remains toxic & 2 & 1 & low \\
\hline Accidentally detonated due to boat collision & 5 & 2 & medium \\
\hline Spontaneous detonation underwater & 3 & 4 & medium \\
\hline Surfaced by dredging or mining operations & 5 & 2 & medium \\
\hline Surfaced due to its own buoyancy & 5 & 2 & medium \\
\hline Accidentally detonated by diver & 6 & 2 & medium \\
\hline Caught in fishing net but not surfaced & 6 & 2 & medium \\
\hline Discovered accidentally or by diver: reported & 6 & 2 & medium \\
\hline Redistributed by dredging or mining & 6 & 2 & medium \\
\hline Surfaced in fishing nets: landed in port & 5 & 3 & medium \\
\hline Detonation results in oceanographic/seismic & 7 & 2 & high \\
activity & & & high \\
\hline Chemical agent: polymerizes over & 7 & 3 & high \\
time/exposure and surfaced in fishing gear & & & high \\
\hline Intentionally removed for detonation & 5 & 7 & very high \\
\hline Surfaced in fishing nets: reported & 5 & 7 & very high \\
\hline Discovered accidentally, but left undisturbed & 6 & 7 & very high \\
\hline Intentionally detonated in situ & 7 & 7 & very high \\
\hline Recovered intact and sold or redistributed & 10 & 4 & very high \\
\hline Surfaced due to weather events & 9 & 7 & 6 \\
\hline Surfaced in fishing nets: not reported & 10 & & \\
\hline
\end{tabular}

When applied to the 21 UXO risk events, five risk events were determined to be very high (red) priorities, although most events were identified as medium priorities. Of the four identified risk events involving chemical ordnance, the only one that ranked above a low priority was the risk of fishermen surfacing and interacting with polymerized mustard (high priority). Interestingly, leaving UXOs in the water had a higher risk than removing them for detonation, even though this is the preferred method of dealing with marine UXOs today (Beddington \& Kinloch, 2005). 


\section{Interaction Pathways}

Using the review of possible risk events and the risk matrix for marine UXOs, a marine manager can determine which events carry the highest risks for a given area. The next step in mitigating these risks is anticipating where and how people might interact with a marine UXO. Predicted interactions are represented in a pathways diagram (Figure 3 ). To produce the pathways diagram, the people affected by marine UXOs were divided into two categories:

UXO professionals and the general public. These were separated because UXO professionals are intentionally seeking UXOs, while members of the general public will only unintentionally discover a UXO in the marine environment. However, as with the risk matrix, the possibility of accidental detonation or exposure must be considered for both professionals and the public. 


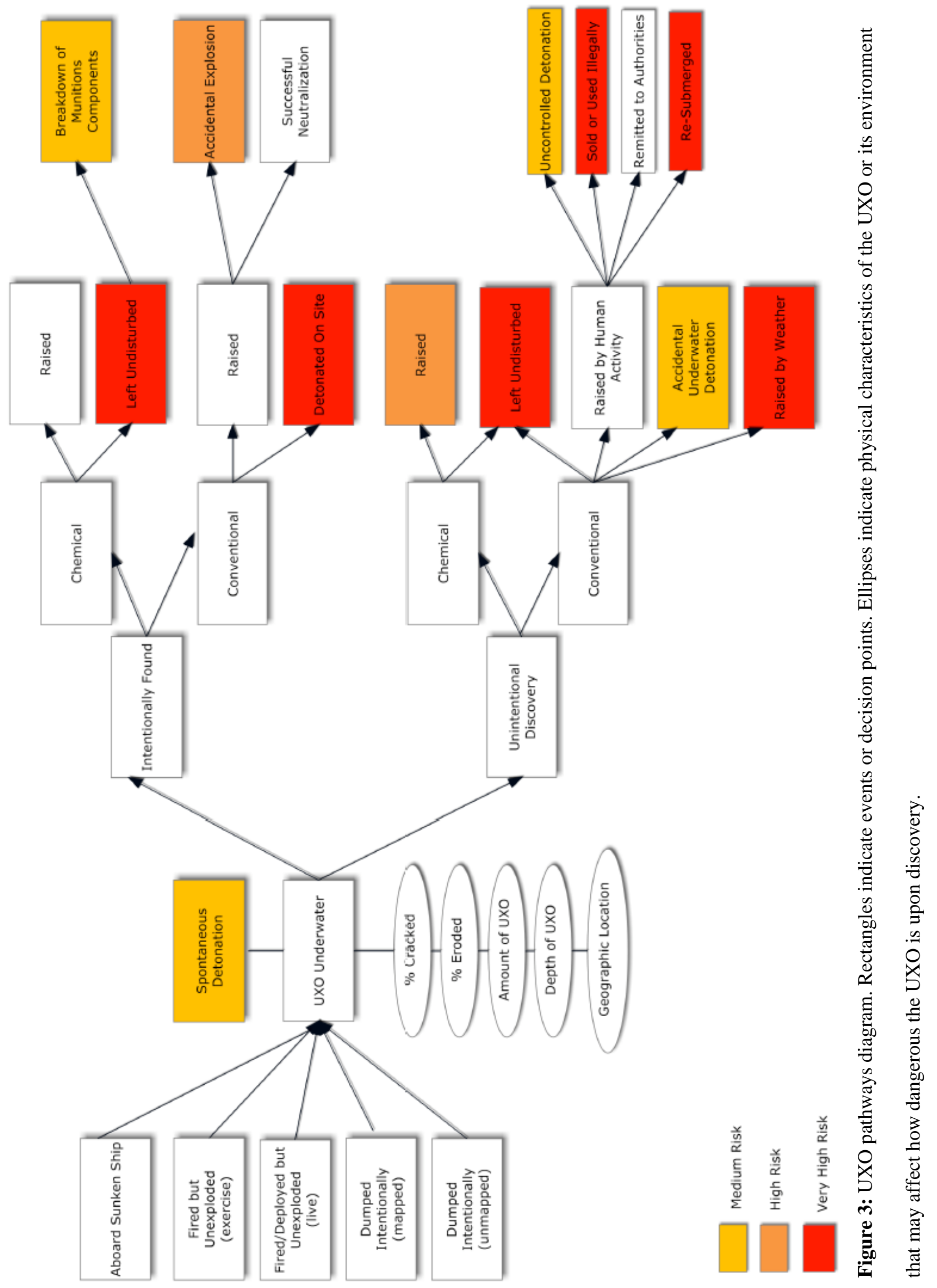




\section{UXO Risk Mitigation Options}

When mitigating the risks associated with UXOs, a range of strategies are available to marine managers. Given that UXOs are discovered by both explosive ordnance professionals and by members of the general public, risk management strategies should consider both of these groups. Mitigation options for incorporating these groups into UXO risk management plans are outlined in the following section. These options are very broad, as they reflect the global nature of the marine UXO problem.

\section{Explosive Ordnance Professionals}

Explosive ordnance professionals are most commonly risk assessors either hired or contracted by organizations with an interest in developing a particular area of the marine environment.

This includes, but is not limited to, companies involved in offshore mining or drilling operations, windmill installation, or coastal infrastructure development. These industries all deal with a fixed piece of property in the marine environment. As such, they have the ability to plan and investigate their submarine real estate before starting development. The following three strategies for risk mitigation by UXO professionals are available to managers who are assessing a marine location for development.

\section{The Desk Survey}

The first and most basic of the risk management strategies available to explosive ordnance professionals is a "desk" survey (Welch, 2010). This non-invasive survey consists primarily of research done on the prospective location in an attempt to determine if records indicate a high likelihood of UXOs. Possible sources of information are undersea surveys, historical reports, private information (company archives), and relevant existing UXO location data. Depending on the available data, these surveys can range from very superficial to remarkably detailed.

Used by many different types of organizations, the primary benefit of the desk survey is that it is a relatively inexpensive exercise requiring very little in the way of specialized equipment. (University of Liverpool, n.d.) While typically done by a contracted third party, desk surveys can be done in-house as well. This type of analysis can be completed in a relatively short time period early on in the risk assessment process, with relatively little risk to the owner of the property.

The main drawback of the desk survey is that it is entirely dependent on pre-existing information. In the case of illegal or unreported UXOs, the desk study may not provide any useful data. In places like the UK, where there is a fairly large body of work on the subject of UXOs, the desk study can work well; however, the desk survey is less effective for poorly surveyed areas. Ocean currents, storm activity, and underwater seismic events can all have a dynamic effect on UXO locations and condition. Additionally, while the desk survey can provide 
a probable location, and perhaps the type of UXO present, it does not eliminate any of the potential consequences of marine UXOs (i.e., property damage, environmental damage, unknown location, or personal exposure).

\section{The Full Survey}

The full survey incorporates all the elements of the desk survey but also adds the element of actual undersea observation. Tools like side scan sonar, underwater video, magnetometers, electromagnetic induction sensors, or specialized systems incorporating many of these different tools, can provide the surveyor with site specific, real time information that would be otherwise unavailable with a desk survey (Bassani, 2008). Once the initial survey data is in, the full survey can incorporate the use of remote operated underwater vehicles (ROVs) or live divers to provide the most accurate information as possible.

The two primary benefits of the full survey are accuracy and detail. A full study may not only provide the location of any UXOs, but a complete picture of the exact number, type, and condition of UXOs as well. This effectively eliminates the potential consequences of the location of UXOs remaining unknown. The full survey surpasses the desk survey in that it can be effective in places where no current data exist. While background research is certainly useful, it is not imperative when a full survey is being conducted.

The main drawbacks of the full survey are time and cost. Specifically, a properly completed full survey involves extensive resources, such as trained technicians to operate the machines and interpret incoming data, and a ship to serve as a base of operations, all of which raise the cost of exploration. Contracting through a third party will increase costs further. Additionally, because the UXOs remain in the marine environment, there is still the risk that they will cause damage or unsafe exposure.

\section{The Comprehensive Plan}

The comprehensive plan takes into account all of the elements of both the desk and full survey, but introduces the process of actually moving, disarming, or disposing of the UXOs. The comprehensive plan is almost always contracted out to specialized consulting companies whose expertise lies in effectively eliminating the risk of UXOs. Depending on the situation, a comprehensive plan will relocate, detonate or otherwise neutralize the UXOs on-site, virtually eliminating the threat entirely.

The comprehensive plan is the most thorough of the three options and the end result is not simply the avoidance of UXO risk, but its veritable elimination. The other benefit of this plan is that by bringing in an outside contractor, much of the risk is transferred to that contractor and the affiliated sub-contractors (Alpha Associates, 2011b). Through the use of the 
comprehensive plan, the explosive ordnance professional can effectively mitigate most of the potential consequences of UXOs.

However, a comprehensive strategy takes extensive time and resources. In addition to finding and identifying UXOs, the logistics of safe and legal disposal need to be considered. In many cases the consultant will coordinate the disposal of the ordnance, although this can increase the cost of the process even more. Due to the additional costs of disposing marine UXOs, the common practice has been to locate and record areas with marine UXOs and forgo disposing of them. While this may be an effective method of reducing costs, it does not completely eliminate the potential consequences identified in the risk assessment matrix.

\section{The General Public}

The general public (anyone who comes into contact with an UXO unintentionally) includes fishermen, divers, sailors, and recreational users of the marine environment. These people will likely have little knowledge of UXOs and will not know how to handle them properly. In contrast to explosive ordnance professionals, mitigation strategies for the general public must focus on public education and enforcement as well as the identification of potentially dangerous areas both on the water and on nautical charts.

\section{Public Hotlines}

Often used by organizations working in other fields, the hotline is a relatively easy and cost effective way for the general public to either report UXOs or find out what to do if they come in contact with them. In particular, a hotline maintained by a third party provider can be a low cost way of communicating the locations of discovered UXOs to an authority and educating the public on how to handle UXOs if discovered (McGladrey \& Pullen, 2011).

However, hotlines are limited in that if UXOs are discovered offshore accessing a phone might not be a viable option. Additionally, as the discovery of underwater UXOs is still a reasonably rare event, it may be hard to justify the need for a dedicated hotline, particularly where local law enforcement officials already provide an established method of communicating UXO events. Aside from the potential to provide timely advice, the hotline does not proactively reduce the occurrence of UXO events.

\section{Location and Education}

As more information becomes available, it is clear that a useful strategy for reducing the probability of the general public interacting with marine UXOs is the creation of a public UXO location database. A database could provide the locations and nature of all known and reported UXO sites, as well as provide a method for allowing the public to add their own independent observations. The benefits, such as the ability to make quantitative searches, 
keep information up to date, and maintain relatively low upkeep costs, make the online database an attractive way to present UXO information (Choo, n.d.). In contrast to relying on hardcopy marine charts to alert users to UXO locations, using an electronic database would allow continuous updates in real time, ensuring that fisherman, recreational divers, and the general public could plan their maritime routes and recreational activities accordingly.

The development of a comprehensive online database is currently restricted by the fact that, in many cases, governments are not willing to provide the data necessary to make such a database effective. For example, the Canadian Government website for the UXO Legacy Program publishes general information about areas and depths, but due to security concerns the exact locations of UXO sites are not provided (Government of Canada, 2008). This is indicative of the largest drawback for the public database model: information could be misused. For example, looting of UXO weapons caches is already happening on land (Hauslohner, 2011), and there is no reason to suppose that it could not happen in the marine environment as well.

\section{Implementation Recommendations}

Before a marine manager can implement a UXO risk mitigation strategy, it is first necessary to determine and prioritize the possible risk events. The risk assessment methodology presented here is a valuable tool in making these determinations. Based on the global assessment of the range of known and plausible risks, it appears that the risk events that result from the UXO remaining undetonated in the environment pose the greatest threat. This finding is significant because it contradicts the most common management practice for discovered marine UXOs, which is to leave them undetonated (Alpha Associates, 2011b). According to this risk assessment, it is advisable that wherever possible, a comprehensive management strategy should be employed, which includes the process of removing UXOs from the marine environment and disposing of them properly.

Currently, the primary barrier to implementing a comprehensive UXO risk mitigation strategy is cost. However, companies engaged in marine development projects are well-funded and the value of UXO surveys is generally well accepted (Chandler, 2011). In addition, UXO legislation is becoming more common around the world and the United Nations is taking an active role in trying to promote the necessity of marine UXO legislation (Geneva International Centre for Humanitarian Demining, 2006).

When UXO removal is not a possibility, the next step for marine managers is to minimize the risk of the public interacting with UXOs. In order to do this, managers must determine the most common circumstances where such interactions occur. A pathways diagram, similar to the one depicted in Figure 3, serves as a tool to achieve this goal. Once the circumstances for 
human/UXO interaction in a particular area have been identified, measures such as location databases and public education can ensure that the risk of human/UXO interaction is reduced.

While there is considerable public focus on land-based UXOs, like land mines, information regarding underwater UXOs is difficult to access. Risk management plans need to be adopted on a national scale, while also satisfying international guidelines, due to the complexities of marine jurisdiction (e.g., the high seas). While current technology cannot completely eliminate UXO risk, investment by the global community in a few relatively small projects, such as an international UXO hotline, or real-time database, could substantially mitigate the risks to people and property. 


\section{References}

Advisory Committee on Protection of the Sea (ACOPS). (2003). Coastal Survey of Packaged Chemical and other Hazardous Items. Maritime and Coastguard Agency Research Project No. 488, London.

Alpha Associates. (2011a). Unexploded Ordnance Risk: Considering Unexploded Ordnance Risk on and around the British Isles. Retrieved from http://www.pmss.com/ downloads/Unexploded\%200rdnance\%20Risk\%203.2.pdf

Alpha Associates. (2011b). Unexploded Ordnance Risk Mitigation - Marine. Retrieved from http://www.6alpha.com/uxo-risk-mitigation-marine

Bassani, C. (2008). SAIC Unexploded Ordnance (UXO) Survey System. Presented at Oceans 2008, in Quebec City, Quebec. 15-18 Sept. 2008. http://dx.doi.org/10.1109/OCEANS.2008.5152124

Bearden, D. (2007). U.S. Disposal of chemical weapons in the ocean: Background and issues for congress. Congressional Research Service. Retrieved from http://www.fas.org/sgp/crs/natsec/RL33432.pdf

Beddington, J. \& Kinloch, A. (2005). Munitions dumped at sea: A literature review. Retrieved from http://www.mod.uk/NR/rdonlyres/77CEDBCA-813A-4A6C-8E59-16B9E260E27A/0 lic munitions seabed rep.pdf

Belden, J., Ownby, D., Lotufo, G. \& Lydy, M. (2005). Accumulation of trinitrotoluene (TNT) in aquatic organisms: Part 2 - Bioconcentration in aquatic invertebrates and potential for trophic transfer to channel catfish (Ictalurus punctatus). Chemosphere, 58(9), 1161-1168. http://dx.doi.org/10.1016/j.chemosphere.2004.09.058

Chandler, G. (2011). Clearing the Way for Winds of Change. Earth Explorer. Issue 1. Retrieved from http://www.earthexplorer.com/2011-08/Clearing the way for winds of change.asp

Choo, C.W. (n.d.). Advantages of Online Database Services. Retrieved from http://choo.fis.utoronto.ca/fis/courses/lis1325/Structure.Adv.html

Crown. (2010). Dealing with munitions in marine sediments. Retrieved from http://www.ramorauk.com/ webedit/uploaded-files/All\%20Files/Dealing-with-munitions-inmarine-sediments-2010.pdf 
Cullison, G. \& Turlington, C. (2004). Overview - Environmental effects of underwater unexploded ordnance (UXO) \& munitions constituents (MC). [Presentation slides]. Retrieved from http://64.78.11.86/uxofiles/enclosures/UnderwaterUXO EnvEffects.pdf.

Davies, G. (1996). 'Munitions Dump Explodes into Headlines Again', News, Marine Pollution Bulletin, 30(3), 250-251. http://dx.doi.org/10.1016/S0025-326X(96)90110-1

Department of National Defense. (2003). Warfare Agent and Disposal Project. Retrieved from http://www.forces.gc.ca/site/news-nouvelles/news-nouvelles-eng.asp?cat=03\&id=1039

Department of National Defense. (2010a). UXO Types. Retrieved from http://www.uxocanada .forces.gc.ca/ut-tu/index-eng.asp

Department of National Defense. (2010b). The DND UXO and Legacy Sites Program. Retrieved from http://www.uxocanada.forces.gc.ca/pro/index-eng.asp

Geneva International Centre for Humanitarian Demining. (2006). Developing Mine Action Legislation - A Guide. Retrieved from http://www.gichd.org/publications/languages/ english/developing-mine-action-legislationa-guide-en

Glasby, T. (1997). Analyzing data from post impact studies using asymmetrical analyses of variance: A case study of epibiota on marinas. Australian Journal of Ecology, 22, 448459.

http://dx.doi.org/10.1111/j.1442-9993.1997.tb00696.x

Government of Canada. (2008). List of Underwater Unexploded Explosives Ordnance (UW UXO) Sites that has been complied from historic research projects conducted on the East and West Coast of Canada. National Defense. Retrieved from http://www.uxocanada. forces.gc.ca/ul-eu/luueosc-Issmmee-eng.asp

Green, A., Moore, D. \& Farrar, D. (1999). Chronic Toxicity of 2, 4, 6-trinitrotoluene to a Marine Polychaete and an Estuarine Amphipod. Environmental Toxicology and Chemistry, 18(8), 1783-1790. http://dx.doi.org/10.1002/etc. 5620180826

Haplin, S. \& Morrison, M. (2009). Marine UXO (Unexploded Ordnance) identification and avoidance for a shallow water pipeline route. Offshore Technology Conference, Houston, Texas. 
Hauslohner, A. (2011). Gaddafi's Abandoned Arsenals Raise Libya's Terror Threat. Time:

World. Sept. 7. 2011. Retrieved from

http://www.time.com/time/world/article/0,8599,2092333,00.html

HELCOM. (1994). Report on chemical munitions dumped in the Baltic Sea. Report to the 15th Meeting of Helsinki Commission. Danish Environmental Protection Agency.

Kehoe, M. (2002). Military dumpsite off Canada's Atlantic Coast. Retrieved from http://www.oag-bvg.gc.ca/internet/English/pet 050A e 28755.html

Kirby, A. (2004). UK's undersea "ticking timebombs." BBC News. London. Retrieved from http://news.bbc.co.uk/2/hi/sci/tech/4032629.stm

Kmec, J., Hreha, P., Hlavacek, P., Zelenak, M., Harnicarova, M., Kubena, V., Knapcikova, L., Macej, T., Duspara, M. \& Cumin, J. (2010). Disposal of discarded munitions by liquid stream. Technical Gazette, 17, 383-388.

Koschinski, S. \& Kock, K. (n.d.).Underwater unexploded ordnance - Methods for a cetaceanfriendly removal of explosives as alternatives to blasting. Retrieved from http://www.iwcoffice.org/ documents/sci com/sc61docs/SC-61-E21.pdf

Lindsay, J. (2010). CG tracks mustard gas that sickened fishermen. Navy Times. Retrieved from

http://www.navytimes.com/news/2010/06/ap military mustardgas boat 060810/

Lotufo, G., Farrar, J., Inouye, L., Bridges, T. \& Ringelberg, D. (2001). Toxicity of sedimentassociated nitroaromatic and cyclonitramine compounds to benthic invertebrates.

Environmental Toxicology \& Chemistry, 20, 1762-177

http://dx.doi.org/10.1002/etc.5620200820

McGladrey and Pullen. (2011). Establishing a hotline is a cost-effective and successful way to detect fraud. Retrieved from

http://mcgladrey.com/Risk-Management/Establishing-a-hotline-is-a-costeffective-andsuccessful-way-to-detect-fraud

McKee, F.M. (1993). An Explosive Story: The Rise and Fall of the Depth Charge. The Northern Mariner: Journal of the Canadian Nautical Research Society, 3, 46.

Monfils, R., Gilbert, T. \& Nawarda, S. (2006). Sunken WWII shipwrecks of the Pacific and East Asia: The need for regional collaboration to address the potential marine pollution threat. Ocean \& Coastal Management, 49, 779-788.

http://dx.doi.org/10.1016/j.ocecoaman.2006.06.011 
Nipper, M., Carr, R., Biedenbach, J., Hooten, R., Miller, K \& Saepoff, S. (2001). Development of marine toxicity data for ordnance compounds. Archives of Environmental Contamination and Toxicology, 41, 308-318. http://dx.doi.org/10.1007/s002440010253

Organization for the Prohibition of Chemical Weapons. (1993). Convention on the Prohibition of the Development, Stockpiling and Use of Chemical Weapons and on their Destruction. Retrieved from http://www.opcw.org/index.php?elD=dam frontend push\&doclD=6357

Schroeder, D. (n.d.). The history of the sea mine and its continued importance in today's navy. Retrieved from http://www.history.navy.mil/museums/keyport/The History of the Sea Mine.pdf

Slade, S. (2000). Are sea mines still dangerous? Retrieved from http://www.slate.com/articles/news and politics/explainer/2000/08/are sea mines still d angerous.html

University of Liverpool. (n.d.). Desk Study and Site Investigation: EOSC316 Engineering Geoscience. Retrieved from http://pcwww.liv.ac.uk/rockdef/lectures/engineering/ 4\%20Site\%20Investigation.pdf

Welch, A. (2010). Alistair Welch investigates the issue of unexploded devices that remain on the seabed - and how this could affect windfarm development. Retrieved from http://www.6alpha.com/downloads/OW AT UXB.pdf

Welch, A. (2010). Risky Business: Offshore Wind Engineering. Autumn 2010. p. 68. Retrieved from http://www.6alpha.com/downloads/OW AT UXB.pdf

Westman, H. (2006). Visualizing the invisible: Visualizing historic shipwrecks. Computer Graphics Quarterly, 40(3). http://dx.doi.org/10.1145/1186743.1186747 